\title{
Implications of Altered Endosome and Lysosome Biology in Space Environments
}

\author{
Ian R. D. Johnson ${ }^{1, *}{ }^{\mathbb{C}}$, Catherine T. Nguyen ${ }^{1}$, Petra Wise ${ }^{2}$ and Daniela Grimm ${ }^{3,4}$ \\ 1 Research in Space Environments Group, UniSA Clinical and Health Sciences, University of South Australia, \\ Adelaide, SA 5000, Australia; ngucy037@mymail.unisa.edu.au \\ 2 Department of Hematology and Oncology, Children's Hospital of Los Angeles, Los Angeles, CA 90027, USA; \\ pwise@chla.usc.edu \\ 3 Department of Microgravity and Translational Regenerative Medicine, Clinic for Plastic, Aesthetic and Hand \\ Surgery, Otto-von-Guericke-University Magdeburg, 39106 Magdeburg, Germany; dgg@biomed.au.dk \\ 4 Department of Biomedicine, Aarhus University, 8000 Aarhus C, Denmark \\ * Correspondence: ian.johnson@unisa.edu.au
}

Received: 20 October 2020; Accepted: 31 October 2020; Published: 2 November 2020

\begin{abstract}
Space exploration poses multiple challenges for mankind, not only on a technical level but also to the entire physiology of the space traveller. The human system must adapt to several environmental stressors, microgravity being one of them. Lysosomes are ubiquitous to every cell and essential for their homeostasis, playing significant roles in the regulation of autophagy, immunity, and adaptation of the organism to changes in their environment, to name a few. Dysfunction of the lysosomal system leads to age-related diseases, for example bone loss, reduced immune response or cancer. As these conditions have been shown to be accelerated following exposure to microgravity, this review elucidates the lysosomal response to real and simulated microgravity. Microgravity activates the endo-lysosomal system, with resulting impacts on bone loss, muscle atrophy and stem cell differentiation. The investigation of lysosomal adaptation to microgravity can be beneficial in the search for new biomarkers or therapeutic approaches to several disease pathologies on earth as well as the potential to mitigate pathophysiology during spaceflight.
\end{abstract}

Keywords: lysosomes; spaceflight; autophagy; bone; muscle; differentiation

\section{Introduction}

Endosomes and lysosomes are critical to the function of every cell in the human body. They are dynamic organelles that mediate adaptation of cell metabolism to environmental cues [1,2]. With a low $\mathrm{pH}$ that regulates hydrolase function, lysosomes are fundamental to the degradation and recycling of cellular material and participate in a multitude of cellular processes such as signalling, cell adhesion, gene regulation, immunity, migration and plasma membrane repair [1]. Endosomes and lysosomes are also essential for autophagy, removal and recycling of cellular compartments and are critical to immune function [3-5]. They are also critical for intercellular signalling; the biogenesis of late endosomes to multivesicular bodies provides a source of extracellular vesicles, known as exosomes, that are enriched for cell-specific proteins and mRNA that can affect target cells through altered protein translation or other signalling events [6]. Disruption to the endo-lysosomal system can significantly affect cell homeostasis and impact tissue and organ function; for example, lysosomal dysfunction contributes to age-related disorders such as Parkinson's and Alzheimer's diseases, neurodegenerative disorders (e.g., mucopolysaccharidosis) and cancer [7-9]. 
Onset of disease pathologies, namely those associated with ageing, can be accelerated in extreme environments such as in space [10-12]. Human physiology is significantly altered in this environment resulting from stressors such as hypergravity $(>1 \mathrm{~g})$, microgravity $(<1 \mathrm{~g})$ and ionising radiation [13]. These induce physiological changes and disease phenotypes similar to those that are observed in ageing-related processes, such as bone atrophy, sarcopenia, accumulative oxidative stress and diminished immune function [14-17]. Indeed, many of the physiological alterations that astronauts exhibit in low-gravity conditions may be attributed to autophagy or alterations in the endo-lysosomal system [18-21].

First described from the physiological changes observed in rat cardiomyocytes on Bion 4 [22] and salivary glands of rats on-orbit in Spacelab 3 [23], there is a growing body of work associating altered autophagic responses to spaceflight or microgravity [21]. Many of the autophagic and lysosomal alterations are summarised in Table 1. These results are derived from observations of alterations to in vitro cell culture systems or the direct action of tail suspension (hindlimb unloading) in rodents on muscle/bone. Interestingly, non-exhaustive meta-analysis of mRNA microarray datasets from space-flown animals or cell lines show alterations in expression of endo-lysosomal or vesicular trafficking genes. For example, significant differential expression of endosome associated proteins such as Rab5 (early), Rab7 (late) and Rab11 (recycling) are observed in space flown mice (GSE94381 [24]) and mesenchymal stem cells (GSE100930 [25]), whilst various kinesins, dyneins or dynactins required for lysosomal trafficking also show significant differential expression. Further evidence of altered endo-lysosomal function during spaceflight is suggested by the near two-fold expression change of transcription factor EB (TFEB; GSE94381), a critical regulator in lysosomal biogenesis. Understanding the role of endosomes, lysosomes and autophagic processes in cellular function and disease pathogenesis in space environments may reveal novel physiological biomarkers and new therapeutic targets or countermeasures against space-related stressors and ageing-related pathologies.

Table 1. The effect of spaceflight or simulated environments on autophagy and the endo-lysosomal system.

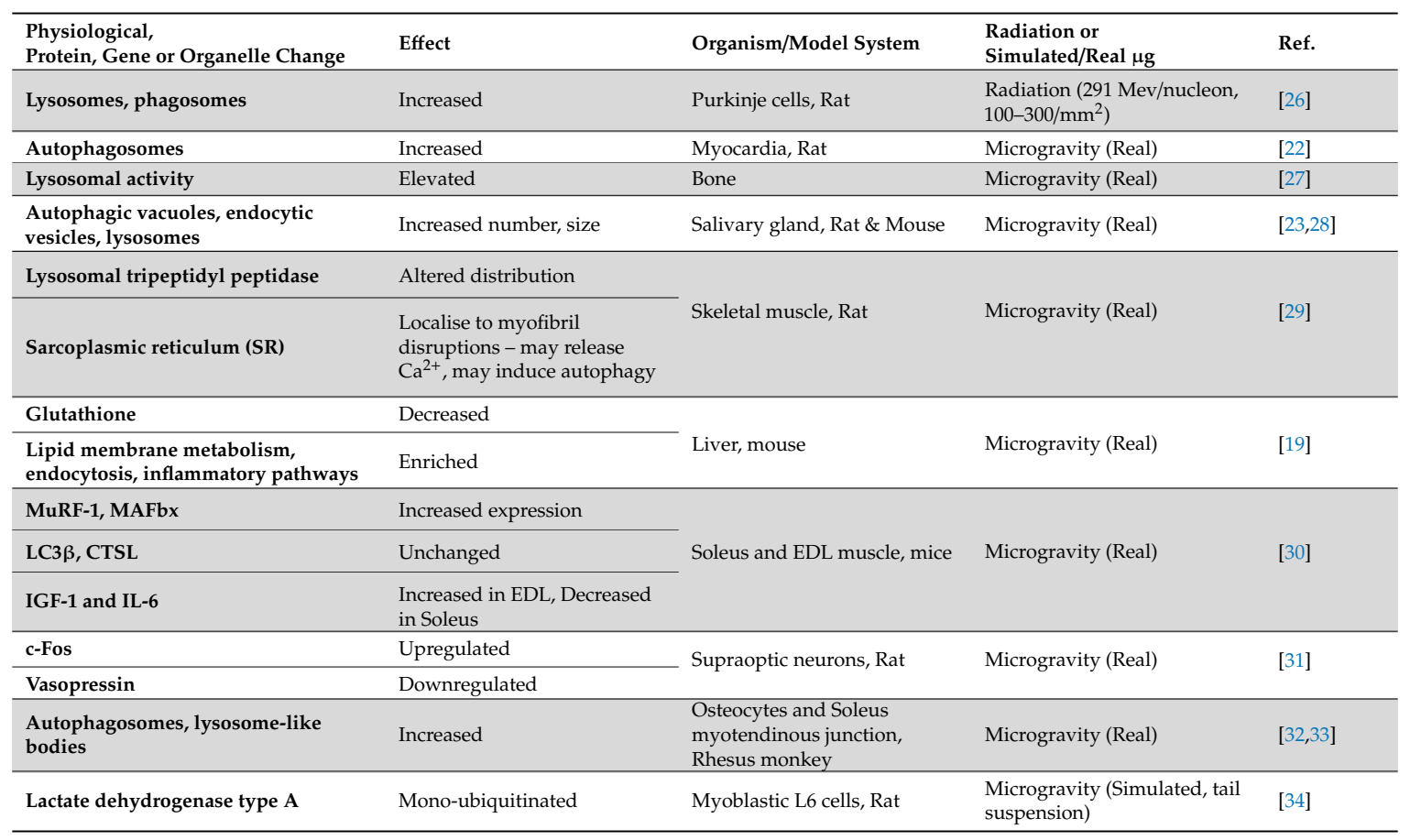


Table 1. Cont.

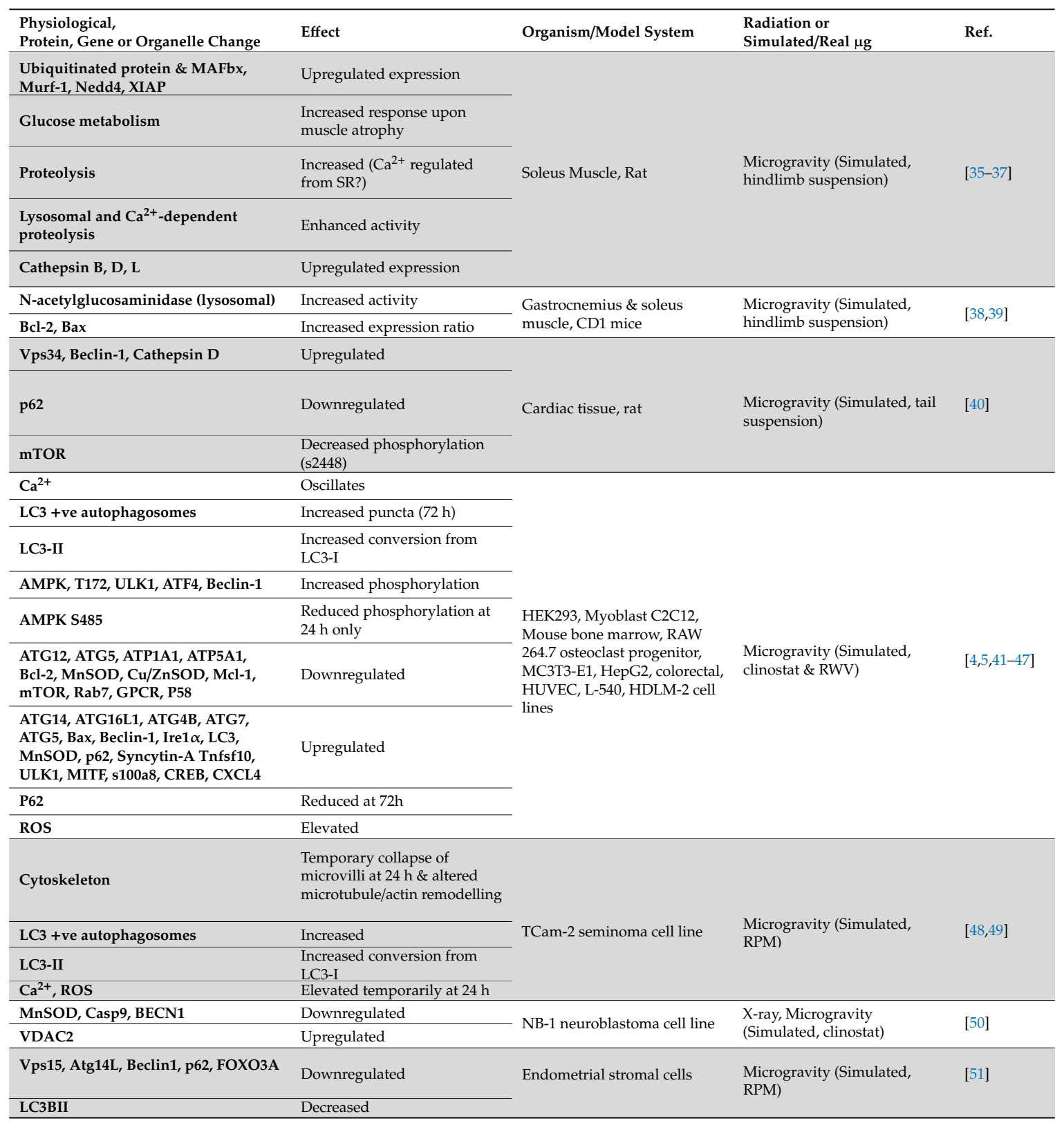

\section{The Endosome-Lysosome System and Autophagy in Microgravity-Induced Pathophysiology}

\subsection{Bone Loss}

The absence of load bearing forces affects living organisms at the macro and microscopic levels, resulting in significant physiological changes that often present as pathologies within bone and muscle $[12,52,53]$. Astronauts lose approximately $10-20 \%$ of their bone mass in microgravity $[54,55]$, mimicking bone atrophy in joints and vertebrae of patients with severe osteoporosis [56-58]. Bone loss rates are skeletal site-specific and range approximately $1 \%$ in thoracic vertebrae and approximately $6 \%$ in spine to over $8 \%$ at the femoral neck or proximal femur after only six months in orbit [59]. Skeletal homeostasis requires a balanced action of osteoclasts for bone resorption and osteoblasts for bone formation. Both are critical in bone mass renewal, remodelling and bone growth [60-63]. Bone loss results from altered osteocyte function within the bone matrix; osteocytes deeply embedded within the mineralised matrix of bone sense mechanical stimuli (mechano-sensation) [56-58], and alter their surrounding environment via mechano-transduction to maintain skeletal homeostasis [64]. 
Skeletal unloading, such as during bed rest, upregulates the expression of sclerostin $[65,66]$, an essential Wnt signalling inhibitor (Figure 1A), and reduces bone formation [67]. In microgravity-simulated conditions of reduced hindlimb loading in rats and osteocyte culture in rotating wall vessels, osteocytes express and secrete increased amounts of sclerostin $[62,63,68]$, inhibiting bone remodelling and regeneration through reduced osteoblast proliferation and differentiation [21]. Like many other secretory proteins, sclerostin secretion and uptake may be tightly integrated with the endosome pathway, with its secretion mediated by vesicular trafficking from the biosynthetic pathway (Figure 1B) and its uptake by clathrin-dependent endocytosis into the endo-lysosomal network (reviewed by Suen and Qin [69]) and degraded by lysosomal hydrolase cathepsin K (Figure 1C) [70]. Whilst secretion is elevated by reduced mechanical load, disruption to endo-lysosomal biogenesis and altered hydrolase function may inhibit the efficient endocytosis and degradation of sclerostin, maintaining its inhibitory effects on Wnt signalling pathways. Interestingly, sclerostin expression is induced by Nupr1 via Runx2 transcription factor [71]. Nupr1, a stress-associated gene, is highly expressed in mature osteoclasts; however, Nupr1-deficient mice show elevated autophagy and apoptosis [71], suggesting that Nupr1 is a protective factor in osteoclast homeostasis or that osteoclasts pre-disposed to elevated Nupr1 will survive spaceflight stressors that induce autophagy and apoptosis. Investigations on the interplay of stress response, autophagy, and the endo-lysosomal system on sclerostin and osteoclast activity in space environments may reveal new insights to maintaining bone health in spaceflight.

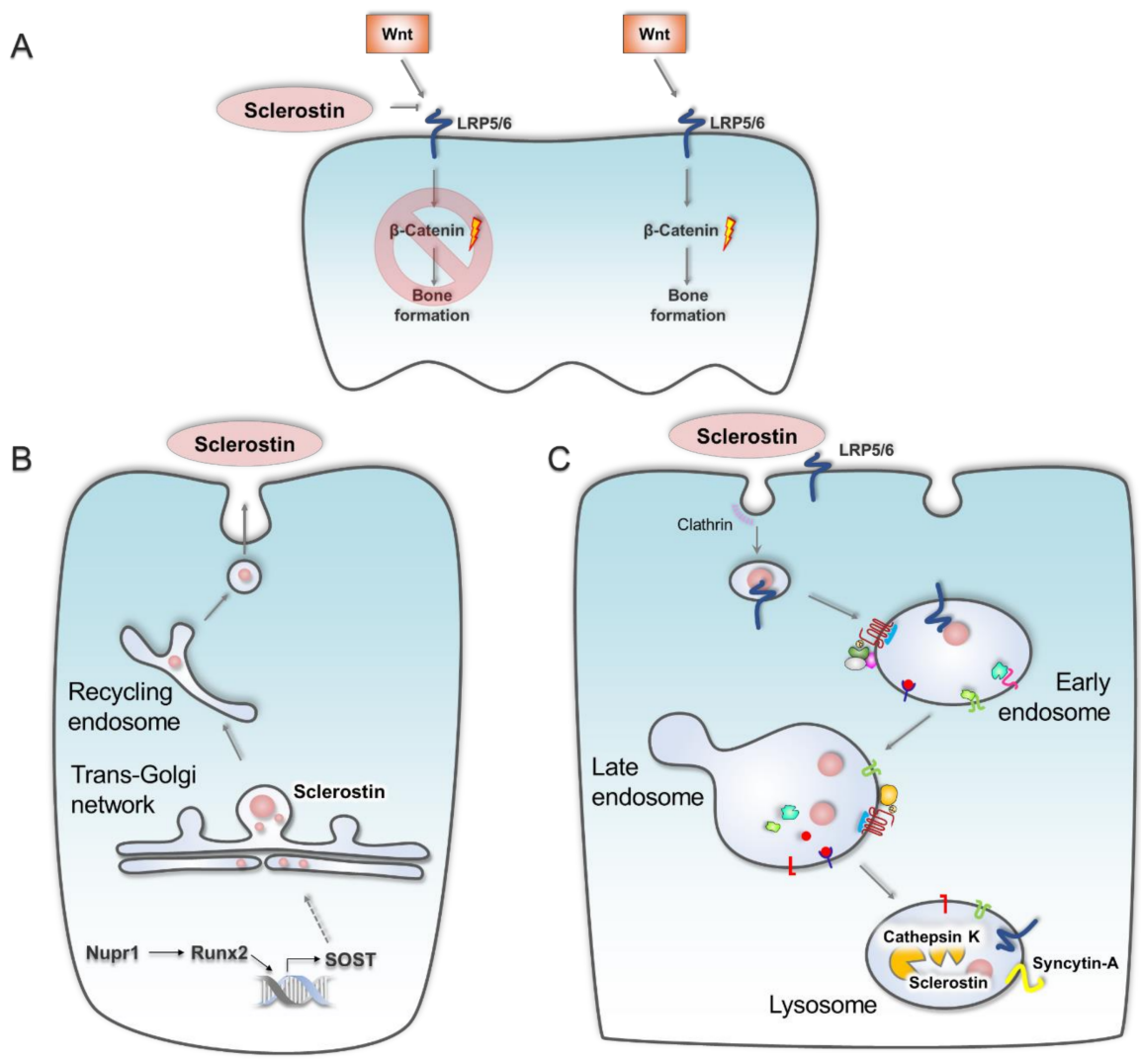

Figure 1. Sclerostin inhibits Wnt signalling through competitive binding to LRP5/6 (A) and requires endo-lysosomal pathways for its secretion (B) and degradation (C).

The endosome-lysosome system has significant roles in osteoblast and osteoclast homeostasis through recycling and degradation of material, cell differentiation and signalling [72,73]. The organelles have critical roles in regulating signal transduction of membrane-bound receptors such as the parathyroid hormone receptor, which affects osteoclasts as well as proximal tubular cells of kidney [73-75]. Stimulation by parathyroid hormone in spaceflight increases the release of $\mathrm{Ca}^{2+}$ 
from bone, inducing nutrient deprivation of osteoclasts $[76,77]$ and increased autophagic activity and lysosome-mediated degradation of the bone under microgravity conditions [73,78].

Lysosomes are essential to the maintenance of bone through acidification of the bone surface, where lysosomal hydrolases are released by exocytosis that demineralises bone matrix $[39,79,80]$. In microgravity conditions, there is both an increase in osteoclast resorption through pit formation [52] and a decrease in osteoblast synthesis and bone regeneration [59,81-83]. Secretion of lysosomal content acidifies the bone surface, degrading the lacuna and enabling resorption of the bone [84]. The ruffled borders of osteoclasts are enriched with vacuolar-type $\mathrm{H}^{+}$ATPase through binding of lysosomes to the membrane, enhancing acidification through active proton transport and ATP hydrolysis across the plasma membrane (Figure 2). Differential expression of endosome proteins such as the late endosome marker Rab7 observed in spaceflight [24,25] significantly impairs the resorption capacity [4], since these proteins are integral to cell polarisation, ruffled border and osteoclast bone resorptive capability $[85,86]$. Furthermore, expression of mannose-6-phosphate receptor (M6PR) is elevated during spaceflight [87] which disrupts lysosome-mediated osteoclast activity through increased M6PR-mediated cathepsin K lysosomal hydrolase secretion and osteoclast resorption [41,87]. This may have deleterious effects on the activity of sclerostin and its inhibitory effects on the Wnt signalling pathways discussed above.

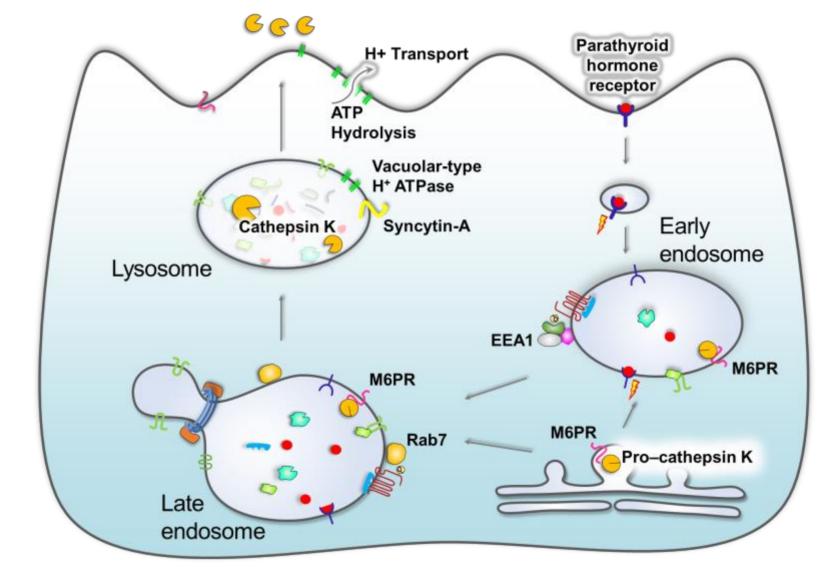

Figure 2. The endo-lysosomal system is essential to bone maintenance through secretion of lysosomal hydrolases and efficient uptake and signalling from endosomal compartments of ligands such as parathyroid hormone. Maturation of lysosomes and plasma-membrane fusion releases lysosomal content to the bone surface and enriches the plasma membrane with proton pumps that enhance acidification. Rab7 is a critical protein in biogenesis of early endosome to late endosomes, and overexpression may increase targeting of lysosomes to the ruffled border. Mannose-6-phosphate receptor (M6PR) may affect cathepsin $\mathrm{K}$ trafficking and secretion, inducing aberrant hydrolysis of extracellular proteins. Arrows depict potential biogenesis and trafficking pathways of secretory and endocytosed proteins.

Restoring the balance of lysosomal exocytosis and cell polarisation may improve bone regeneration under microgravity conditions and overall bone health [73]. Ethiraj et al. [5] showed that microgravity induces the syncytin-A expression in RAW264.7 preosteoclast cells without RANKL stimulation. The syncytin-A expression co-localised with lysosomes in preosteoclast cells and acridine orange staining showed RANKL elevated autophagy activity (see Figure 2). Moreover, siRNA suppression of syncytin-A clearly reduced the autophagy activity in the cells. The authors suggested that targeting the syncytin-A expression as an interesting countermeasure to reduce bone loss in space [5]. In a recent study Ethiraj et al. [88] also demonstrated that proteasome inhibition via MG-132 treatment abolishes RANK expression in preosteoclast cells. The authors reported that MG-132 also supresses microgravity-induced elevated osteoclast differentiation and bone resorption, further supporting the hypothesis of RANK involvement in the process. Similarly, protease inhibition has been shown to 
suppress K48-linked poly-ubiquitin proteins, suggesting that the ubiquitylation of proteins plays a role in suppression of RANK receptor expression in preosteoclast cells [88].

Furthermore, elevated osteoclast formation coincides with increased expression of Atg5 and LC3-II autophagic markers, autophagosome formation and the upregulation of inflammatory cytokines in microgravity environments [4]. As shown in Table 1, there are significant number of studies in simulated and real microgravity that display autophagic markers such as LC3 and Atg proteins and increased autophagosomes depicted by increased puncta. Autophagy is integrally linked to the endo-lysosomal system, utilising many of the same machinery. Recently, Nakamura et al. described how activation of LC3 by lipid attachment is essential for autophagosome formation [89]. Interestingly, lipidated LC3 activates TFEB, a critical transcription factor for lysosome biogenesis and autophagy [90]. The mechanism of this upregulation remains to be elucidated; however, the elevated expression of TFEB in microgravity [24] and evidence of LC3-mediated TFEB activation strongly suggests that lysosomal biogenesis is altered and that autophagy and stress response has a role in these processes.

Expression of S100A8, a calcium binding protein that has pivotal roles in autophagy, is significantly upregulated in microgravity and may contribute to the increased cathepsin K activity observed in microgravity-exposed mouse bone marrow-derived preosteoclast cells [41]. This suggests that modulation of autophagy and lysosomal function may remediate the increased osteoclast bone resorptive ability, osteoclast differentiation and reduced bone formation observed in spaceflight. The biogenesis of the endo-lysosomal network is tightly controlled by expression of Rab GTPases such as Rab7 and transcription factors such as TFEB. Indeed, exosomes formed through maturation of late endosomes may be critical to bone homoeostasis (Reviewed by Gao et al. [91]); thus, endos-lysosomal biogenesis may have significant consequences in osteoclastogenesis and bone resorption, highlighting the need to investigate their roles of bone remodelling during spaceflight. Additionally, autophagy and exosome biogenesis seem to be directly linked via shared organelles and molecular machinery. A report from Guo et al. [92] presents a mechanism where autophagy-related proteins like ATG5 and ATG16L1, among others, are directly involved in the regulation of the fate of multivesicular bodies and latterly exosome biogenesis [92]. Autophagic machinery has been observed within exosomes and suggest a strong link between autophagy and exosome biogenesis (reviewed by Gudbergsson [93]). Indeed, recent initial analyses hint to substantial changes in exosome release and distribution of subtypes in cell culture supernatants collected from a controlled experiment on the International Space Station (ISS) in comparison to the ground control (unpublished data, from personal conversation). This leads to the question about the modifications in cell-cell communication via a possible adaptation of the exosomal payload or simply an altered dose response to the micro-vesicular transfer of information and the possible involvement of the wider endo-lysosomal system in this adaptive reaction.

\subsection{Muscle Atrophy}

Mitochondria are essential to the correct function of myofibre and muscle cells, and regulation of metabolism in these cells are significantly affected by autophagic processes [3]. Remodelling of the mitochondrial network, selective removal of mitochondria via autophagy (mitophagy) or mitochondrial reactive oxygen species (ROS)-activated autophagy may lead to the accumulation of dysfunctional and damaged mitochondria that contributes to myofibre and muscle degradation $[94,95]$. These processes can be induced by factors including cancer, ageing [96], and disuse [97], and are frequently observed in immobile elderly populations and in patients undergoing prolonged bed rest recovery [58,98]. Muscle atrophy resulting from altered protein turnover rates can be detected by elevated urinary amino acid excretion $[77,99]$. During the first 28 days on-orbit in Skylab missions SLS1 and SLS2, the average urinary amino acid concentration from atrophying muscles increased by $55 \%$ and proportionate to the time spent in orbit [100]. Proteolysis requires lysosomal hydrolases such as Cathepsin L, that are shown to be upregulated in the muscle of rodents exposed to microgravity or hind-limb unloading experiments (Table 1). Without countermeasures, microgravity-induced mitophagy increases the number of slow type I muscle fibres and reduces fibre diameter and myofibril size, eliciting significant 
muscle atrophy $[58,101,102]$. Alterations to muscle structure and function primarily affects leg extensor muscles and postural muscles though a reduction in fibre size [58], pennation angle and sarcomere length $[12,18]$, which may be attributed to lysosome-mediated mitophagy. These processes require expression of specific machinery such as Bnip3 and Bnip3L that bind LC3 and recruit autophagosomes to mitochondria [103]; indeed, inhibiting Bnip3 can reduce muscle wastage [104]. Interestingly, Bnip3 is downregulated in microgravity [105], suggesting an impairment of mitophagy with significant deleterious effects to muscle homeostasis, and a potential accumulation of damaged and dysfunctional mitochondria [95]. Moreover, Ma et al. suggest that in TFEB-overexpressing Bnip3-positive cells, more autolysosomes, and an increased ratio of lysosomes compared to autophagosomes are observed that may restore autophagosome processing and attenuate Bnip3-induced cell death [106]. TFEB is emerging as a critical factor in mitochondrial quality control and maintaining metabolic homeostasis; indeed, skeletal muscle TFEB-deficient mice have been shown to have impaired muscle energy balance and mitochondrial homeostasis-related genes are downregulated [107]. The critical role of TFEB in cell homeostasis (provided in a comprehensive review by Wang et al. [108]) suggests that it may play a pivotal role to cell response of microgravity and may be a targetable candidate for therapeutic countermeasures.

Stressors such as inflammation or starvation invoke muscle proteolysis through Forkhead Box (Fox) $\mathrm{O}$ transcription factor that is pivotal to the activation of autophagy-lysosome pathways [109]. FOXO3 overexpression has been shown to increase protein degradation via lysosomes in atrophied myoblast cells [110]. Whilst there is evidence of FOXO activation of lysosomal degradation and autophagy, the targets of these mechanisms must be elucidated. More detail on molecular mechanisms of muscle atrophy, including FOXO action, are described in a recent review by Ehmsen and Hoke [111]. Interestingly, in microgravity-exposed C. elegans, DAF-16, a FOXO ortholog, displays both elevated expression, and increased nuclear localisation in microgravity, suggesting that lysosomal activity is increased [112]. Lysosomal activity plays a significant role in the longevity of C. elegans [113], with evidence found recently that lysosomes may be critical to mitochondria signalling via lipid pools that enhance mitochondrial function and organism health [114]. Unilateral lower limb suspension does not appear to affect the expression of these in male humans [115], suggesting that microgravity plays a wider role in muscle atrophy via changes in lysosomal activity. In rodents exposed to real or simulated microgravity (see Table 1 for references), soleus muscle and myocardia display significant autophagy activity, ranging from increased numbers of autophagosomes and autophagy-related proteins, upregulated expression and activity of lysosomal hydrolases to ubiquitination to altered distribution of lysosomes (detected by lysosomal tripeptidyl peptidase) to the sarcoplasmic reticulum. The close association of lysosomes with the sarcoplasmic reticulum suggests a role of calcium signalling from lysosomes that may enhance calcium release from the sarcoplasmic reticulum that may initiate autophagic responses [116,117]. The role of calcium in autophagy is beyond the scope of this review; however, Bootman et al. review the intrinsic link between calcium and the pro- and anti-autophagic effects that exist in cells [118]. The role of lysosomes in mitochondrial function/regulation and their importance in age-related disorders that are enhanced during spaceflight highlight the importance of investigations of lysosomal function and autophagy during spaceflight that may provide new insight or countermeasures against muscle dysfunction in ageing and immobile populations.

\subsection{Cell Differentiation}

Cell differentiation is regulated by autophagy and lysosomal signalling [119] and many studies have uncovered associations of endosome-lysosome proteins with stem cell function. For example, lysosome-associated Rab GTPase Rab44 negatively regulates osteoclast differentiation when overexpressed [120]. Indeed, its depletion affects lysosomal $\mathrm{pH}$ and lysosomal $\mathrm{Ca}^{2+}$ influx that is critical for osteoclast differentiation $[120,121]$. The functions of Rab44 have yet to be fully elucidated and may be of significance to changes observed in spaceflight. Villegas et al. have recently reported that mouse embryonic stem cell differentiation is driven by a change in distribution 
of the lysosomal transcription factor TFE3 from the nucleus, where it promotes stem cell renewal, to the cytoplasm where lysosomal Rag GTPases inactivates TFE3 and subsequently promotes cell differentiation [122]. mTORC1 protein complex is critical to this process; in its role in cell response to environmental cues, activation of mTORC1 deactivates TFE3. Inactive mTORC1 results in TFE3 translocation to the nucleus that induces autophagy and upregulation of lysosome target genes, and thus, the reduced phosphorylation or downregulation of mTOR observed in simulated microgravity studies (Table 1), for example Myoblast C2C12 cells or HUVEC endothelial cells. A recent review details the requirement of autophagy in stem cell differentiation [123]. Indeed, this suggests that, in spaceflight, cell differentiation will be significantly altered-significant changes to the expression of autophagic machinery occur in microgravity that may critically affect stem cell populations and affect broad aspects of human physiology [85,124], for example, the ability to regenerate and repair damaged tissues and to maintain the haemopoietic system. In microgravity, stem cell precursors accumulate in bone marrow though a partial inhibition of the progenitor-to-differentiated cell transition through cell cycle arrest and activation of cellular quiescence and senescence [85,125]. Osteoblast differentiation may also be affected through morphological alterations autophagy and lysosomal degradation $[52,53,126]$. Microgravity may therefore create a broad inhibition of stem cell-based tissue regeneration, significantly affecting long-term survival in space [19].

Microgravity may provide new avenues to study stem cell differentiation and to investigate disease pathogenesis. Through cumulative mitochondrial damage, increased autophagy and stem cell clearance, and downregulation of cell signalling pathways, loss of cell stemness is induced in this environment $[119,125]$. The cytoprotective mechanisms of autophagy against stresses such as oxidative stress and DNA damage prevent chromosomal instability, and these may both inhibit and promote tumourigenesis $[123,127]$. In cancer stem cells starved of oxygen and nutrients, autophagy is upregulated and promotes cancer survival, decreasing the effectiveness of anticancer treatments [123]. Interestingly, under simulated microgravity conditions, cancer cell lines differentiate into two phenotypes [125]; one growing adherently on the bottom of the culture flask and one that assembles into spheroids or organoids. The phenotypes may develop from autophagic pathways initiated in stem-like cells that are present in previously assumed "homogenous" cell lines [128], and provide in vitro conditions to study the effects of cancer treatments on patients, providing significant benefits to the study of heterogenic diseases such as cancer $[125,126]$. Thus, investigation of spheroid or organoid development in microgravity may elucidate the role of autophagy in disease pathogenesis.

\subsection{Oxidative Metabolism}

Spaceflight promotes significant oxidative stress, and reactive oxygen species (ROS) production may reduce the metabolic rate of muscle and increase the rate of bone loss in microgravity [129], decreasing longevity of astronauts in spaceflight [130]. Oxidative stress is a consequence of microgravity-induced changes to cells and those of cosmic radiation in the form of protons and heavy ions (e.g., Fe, Si and O). These particles result in damage to proteins, lipids and DNA [131,132], and may induce oxidative stress either through activation of autophagy to remove damaged cell components or directly through linear transfer of energy from these particles and stripping of electrons from atoms and molecules producing free radicals within the cell [133].

There is increasing evidence to suggest that ROS activates genes-promoting tumour metastasis [134]. In the Mir and LMS missions, Stein et al. observed elevated 8-OH-dG levels during spaceflight compared to bedrest controls [135] that may be a result of microgravity or increased ionising radiation that significantly affects mitochondrial electron transport chains, affecting ROS production [136]. ROS production enhances muscle and bone atrophy during spaceflight, creating changes to the cytoskeletal structure, altering adhesion molecule expression, integrins and actin-associated proteins that could result in vascular ageing [137]. Using simulated microgravity, Ran et al. found increased ROS in mouse embryonic stem cells [138]. Yun et al. have recently published a comprehensive review of the role of autophagy in oxidative stress, detailing the changes occurring in mitochondria [139]. 
Mitochondria are a major source of cellular ROS and are frequently damaged or become dysfunctional in microgravity [95]. In turn, this may induce accumulation of enlarged endo-lysosomal structures and impairment of lysosomal acidification and activity [140]. Enlargement of endo-lysosomal structures are regulated by TRPML1, an ion channel that resides in late endosome and lysosome compartments [140]. Activation of TRPML1 from elevated ROS induces the release of lysosomal $\mathrm{Ca}^{2+}$ to the cytosol and disruption to osteoclastogenesis [121,141]. TRPML1-dependent $\mathrm{Ca}^{2+}$ release also induces a signalling cascade mediated by TFEB, increased autophagy, and elimination of damaged mitochondria and excess accumulation of ROS [141].

Whilst ROSs are small enough to diffuse through the cell, their localisation to specific compartments activate receptors and initiate specific redox signalling responses [142]. Endosomal compartments are vital sources of NADPH oxidase (NOX)-generated ROS species that are vital to initiating autophagic responses to oxidative stress [143,144]; endosome-localised NOX2 enzymes catalyse NADPH reduction that induces mitochondrial and nuclear DNA damage and apoptosis [138,145]. ROS-generating endosomes (also known as redoxosomes) can augment signalling of endocytosed receptors that can induce mitochondrial dysfunction-induced apoptosis and from lipids such as C2-ceramide [146,147]. NOX-generated ROSs have critical roles in oxidative inhibition of protein tyrosine phosphatases (PTPs) that are vital to insulin response. Interestingly, insulin resistance is observed during spaceflight $[148,149]$ that may be attributed to an imbalance of mitochondrial and NOX-generated ROS. Mitochondrial and cytoplasmic ROS are finely balanced in response to glucose and insulin. $\mathrm{H}_{2} \mathrm{O}_{2}$ generated by endosomal NOX oxidise and inactive PTPs such as PTEN supresses the development of insulin resistance (reviewed in [150]). Endosome and lysosome function may determine subcellular response to ROS during spaceflight and may provide pathways to target aberrant ROS production, reducing detrimental outcomes of spaceflight including targeting insulin resistance in long duration spaceflight.

\subsection{The Lysosomal System as a Monitor for Physiological Stress}

Spaceflight induces significant pathophysiological changes to the body resulting from stresses at the cellular level. In addition to the involvements of the endo-lysosomal system detailed above, in response to microgravity, human physiology may be critically affected by changes to microbiomes and altered immune responses. Understanding the effects of microgravity on immunosuppression is important in spaceflight, as potential biomarkers may be released from the endo-lysosomal system and may provide a means for targeting through development of new pharmacological interventions for diseases [151]. For example, the pro-inflammatory cytokine IL- $1 \beta$ is located within lysosomes and is a potent activator of osteoclastogenesis which enhances resorption. Downregulation of IL- $1 \beta$ indicates impairment of the osteoclastogenesis activation pathway and inhibition on bone formation seen in spaceflight [152]. Suppression of IL-1 $\beta$ signalling occurs through autophagic activation of p62 degradation via the lysosomal pathway, causing ubiquitinated protein aggregates and proinflammatory responses [153]. IL-1 $\beta$ may be used as a potential biomarker for spaceflight-induced stress, and investigation of its role in response to spaceflight may further advance our understanding of various diseases such as neurodegeneration and muscle disorders [153].

Multiple cathepsins such as cathepsin L have been shown to be related to accelerated muscle atrophy in microgravity; in vitro, upregulation of cathepsin L degrades myofibrillar proteins leading to muscle atrophy [154]. Cathepsin L was shown to be upregulated in microgravity [41], making it a potential biomarker for muscle atrophy analysis [154] or lysosomal function in general.

Endosomal NOX2 may further serve as a potential biomarker for stress and countermeasure response, as its elevation in spaceflight contributes to oxidative stress $[155,156]$. The accumulation of NOX2 correlates with increased ROS production, increasing endothelial cell proliferation [145]. There is a dearth of knowledge regarding NOX2 that must be addressed; inhibition of this enzyme also has immunosuppressive potential [155], and altered endo-lysosomal function may significantly affect NOX2 activity, changing the critical ROS balance required for correct cell function. The study 
of endosomes and lysosomes in space environments may reveal many more pathways to provide countermeasures to long-term spaceflight and to an ageing population on Earth.

\section{Discussion and Conclusions}

Lysosomes are acidic single-membrane-bound cytoplasmic organelles containing soluble hydrolytic proteins enabling the degradation of material from the endocytic and autophagic pathways. They remove unnecessary or dysfunctional cell components and proteins to maintain a balance of synthesis, degradation and recycling for proper cell differentiation and organ development. Disruption to lysosomal function can have significant deleterious effects to human development and may be critical to cancer pathogenesis. As such, the changes to lysosomal function induced by both microgravity and ionising radiation may be a significant factor in increasing cancer risk from spaceflight. Indeed, altered differentiation of cells in microgravity affects macrophage maturation, further impacting cancer pathogenesis.

The complexity of the lysosomal system is depicted in Figure 3, showing a fraction of the involvement of endosomal/lysosomal functions in cells that are affected in space environments, whether through their involvement in secretion of Wnt inhibitors or hydrolases or their roles in ROS production or calcium signalling resulting in increased autophagy. Stressors experienced in spaceflight such as microgravity change cell homeostasis with effects frequently resembling ageing such as loss of muscle and bone mass. The study of many systems has relied on cell lines, which may already have a propensity for a particular biological pathway that may not reflect true biological responses. Likewise, the exposure to radiation in cyclotrons may not reflect real radiation either on-orbit or during spaceflight to Mars. Clinostat or Random positioning machine (RPM) microgravity simulation may also produce shear forces and physical response of cells not observed during spaceflight. However, it is encouraging that many autophagic responses are observed in both real and simulated microgravity both in cell cultures and animals.

Each biological system affected by these stressors is closely reliant on endosome or lysosome function, whether through secreted hydrolases that degrade bone matrix or through autophagic response and recycling of macromolecules. Autophagy and lysosomal activity have been shown to be elevated in both simulated and real space environments, with increased numbers of autophagosomes observed as early as the 1980s. These may be a response to temporary collapse of the cytoskeleton and initiation of starvation responses resulting from failed endocytosis and trafficking resulting in increased autophagic gene expression and activity. Long-term studies on the lysosomal system may reveal new candidate biomarkers for monitoring physiological stress and responses to therapeutic countermeasures, such as when reducing intracellular ROS. These countermeasures may need to target the endo-lysosomal system to regulate autophagic responses, to minimise muscle and bone loss or to minimise deleterious effects on stem cells that are critical to, amongst others, gut function. To examine these systems, secreted biomarkers such as within extracellular vesicles (e.g., exosomes) or soluble lysosomal proteases can be collected. Sufficient quantities can be obtained through long-term culture in simulated microgravity (e.g., RPMs). Antibody-based detection of specific markers with microfluidic devices may enhance this analysis. Technology development here may be implemented to on-orbit experiments and be readily translatable to detection of biomarkers in blood plasma. Significant endo-lysosomal biology can be realised using techniques such as confocal laser scanning microscopy. Samples may be readily fixed in real or simulated microgravity or radiation fields and analysed later. Live cell imaging adds an important dimension to the investigation of lysosome biology; however, implementation of this must achieve enough resolution-lysosome vesicles can be as small as $50 \mathrm{~nm}$ in diameter. Furthermore, analysis of lysosome and endosome trafficking may require long-term imaging in microgravity environments that are only suitable for on-orbit systems. To reach these goals of providing real-time cell biology analysis, in June 2020, Yokogawa's CSU-W1 Confocal Scanner unit arrived in the Japanese Experiment Module of the ISS. Likewise, the FLUMIAS (Fluorescence-Microscopic Analyses System for Life-Cell-Imaging in Space) spinning disk confocal 
laser fluorescence microscope represents a new imaging capability for live cell imaging experiments on suborbital ballistic rocket missions $[157,158]$. Thiel et al. reported the first successful operation of the FLUMIAS-DEA, a miniaturized high-resolution 3D fluorescence microscope on the International Space Station (ISS) [159]. The available real-time analysis technology on the ISS will extend the current knowledge about the dynamics of cellular reactions and adaptations to microgravity in the future.

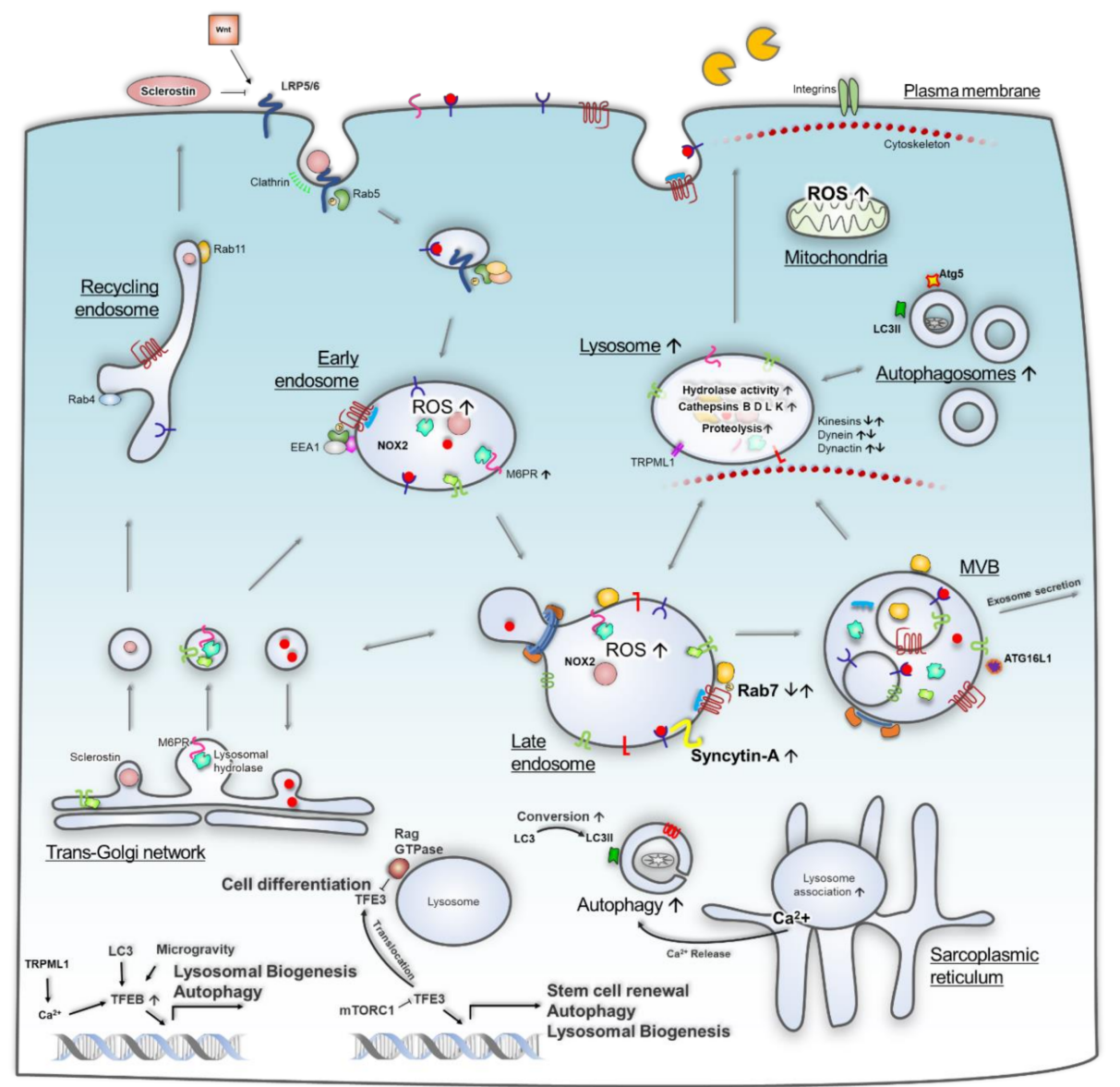

Figure 3. The endo-lysosomal system is a complex pathway that is vital to countless processes in the cell, and its dysfunction results in the hallmarks of many diseases. Shown here are some of the findings from studies detailed in this review, revealing many alterations to cell biology in microgravity that are associated with endosomes and lysosomes. Further research into alterations of the endo-lysosomal system in space may provide substantial new knowledge in its involvement in disease pathogenesis to provide new biomarkers or therapeutic targets. $\downarrow \uparrow$ depicts up- and downregulation observed in spaceflight or associated analogues. Grey arrows depict potential lysosomal biogenesis trafficking pathways. Black arrows depict action/downstream effects on proteins and pathways.

In conclusion, through investigations of the endosome and lysosome system and its role in response to physiological stresses in space environments, we may obtain greater understanding of its importance in human development and disease pathogenesis, with potential to provide better diagnostic biomarkers to disease onset and potential targets for therapeutic countermeasures.

Author Contributions: Conceptualization, I.R.D.J.; writing, I.R.D.J., C.T.N., P.W. and D.G.; review and editing, I.R.D.J., P.W. and D.G. All authors have read and agreed to the published version of the manuscript.

Funding: Costs associated with publishing this review was supported by University of South Australia Research Themes Investment Scheme. D.G was funded by Deutsches Zentrum für Luft-und Raumfahrt (DLR), BMWi project 50WB1924. 
Acknowledgments: We thank C. Tahimic, University of North Florida for insights and suggestions provided for this review.

Conflicts of Interest: The authors declare no conflict of interest.

\section{Abbreviations}

$\begin{array}{ll}\mu \mathrm{g} & \text { Microgravity } \\ \text { ROS } & \text { Reactive oxygen species } \\ \text { TFEB } & \text { Transcription factor EB } \\ \text { RPM } & \text { Random positioning machine } \\ \text { RWV } & \text { Rotating wall vessel } \\ \text { SR } & \text { Sarcoplasmic reticulum } \\ \text { EEA1 } & \text { Early Endosome Antigen 1 } \\ \text { M6PR } & \text { Mannose-6-phosphate receptor } \\ \text { TRPML1 } & \text { Transient receptor potential cation channel 1 }\end{array}$

\section{References}

1. Ballabio, A.; Bonifacino, J.S. Lysosomes as dynamic regulators of cell and organismal homeostasis. Nat. Rev. Mol. Cell Biol. 2020, 21, 101-118. [CrossRef]

2. Luzio, J.P.; Hackmann, Y.; Dieckmann, N.M.; Griffiths, G.M. The biogenesis of lysosomes and lysosome-related organelles. Cold Spring Harbor. Perspect.Biol. 2014, 6, a016840. [CrossRef] [PubMed]

3. Sandri, M. Protein breakdown in muscle wasting: Role of autophagy-lysosome and ubiquitin-proteasome. Int. J. Biochem. Cell Biol. 2013, 45, 2121-2129. [CrossRef] [PubMed]

4. Sambandam, Y.; Townsend, M.T.; Pierce, J.J.; Lipman, C.M.; Haque, A.; Bateman, T.A.; Reddy, S.V. Microgravity Control of Autophagy Modulates Osteoclastogenesis. Bone 2014, 61, 125-131. [CrossRef] [PubMed]

5. Ethiraj, P.; Link, J.R.; Sinkway, J.M.; Brown, G.D.; Parler, W.A.; Reddy, S.V. Microgravity Modulation of Syncytin-a Expression Enhance Osteoclast Formation. J. Cell Biochem. 2018, 119, 5696-5703. [CrossRef] [PubMed]

6. Hessvik, N.P.; Llorente, A. Current Knowledge on Exosome Biogenesis and Release. Cell Mol Life Sci. 2018, 75, 193-208. [CrossRef] [PubMed]

7. Johnson, I.R.; Parkinson-Lawrence, E.J.; Shandala, T.; Weigert, R.; Butler, L.M.; Brooks, D.A. Altered Endosome Biogenesis in Prostate Cancer Has Biomarker Potential. Mol. Cancer Res. 2014, 12, 1851-1862. [CrossRef]

8. Fennelly, C.; Amaravadi, R.K. Lysosomal Biology in Cancer. Methods Mol. Biol. 2017, 1594, $293-308$. [PubMed]

9. Zhang, L.; Sheng, R.; Qin, Z. The Lysosome and Neurodegenerative Diseases. Acta. Biochim. Biophys. Sin. 2009, 41, 437-445. [CrossRef] [PubMed]

10. Carmona-Gutierrez, D.; Hughes, A.L.; Madeo, F.; Ruckenstuhl, C. The Crucial Impact of Lysosomes in Aging and Longevity. Ageing Res. Rev. 2016, 32, 2-12. [CrossRef]

11. Vernikos, J.; Schneider, V.S. Space, Gravity and the Physiology of Aging: Parallel or Convergent Disciplines? A Mini-Review. Gerontology 2010, 56, 157-166. [CrossRef]

12. Demontis, G.; Germani, M.M.; Caiani, E.; Barravecchia, I.; Passino, C.; Angeloni, D. Human Pathophysiological Adaptations to the Space Environment. Front. Physiol. 2017, 8, 547. [CrossRef]

13. Kourtidou-Papadeli, C.; Papadelis, C.L.; Vernikos, J.; Bamidis, P.D.; Hitoglou-Antoniadou, M.; Perantoni, E.; Vlachogiannis, E. The Therapeutic Benefits of Gravity in Space and on Earth. Hippokratia 2008, 12, $28-31$. [PubMed]

14. Orwoll, E.S.; Adler, R.A.; Amin, S.; Binkley, N.; Lewiecki, E.M.; Petak, S.M.; Shapses, S.A.; Sinaki, M.; Watts, N.B.; Sibonga, J.D. Skeletal Health in Long-Duration Astronauts: Nature, Assessment, and Management Recommendations from the Nasa Bone Summit. J. Bone Miner. Res. 2013, 28, 1243-1255. [CrossRef]

15. Strollo, F.; Gentile, S.; Strollo, G.; Mambro, A.; Vernikos, J. Recent Progress in Space Physiology and Aging. Front. Physiol. 2018, 9, 1551. [CrossRef]

16. Grimm, D.; Egli, M.; Krüger, M.; Riwaldt, S.; Corydon, T.J.; Kopp, S.; Wehland, M.; Wise, P.; Infanger, M.; Mann, V.; et al. Tissue Engineering under Microgravity Conditions-Use of Stem Cells and Specialized Cells. Stem Cells Dev. 2018, 27, 787-804. [CrossRef] 
17. Steller, J.G.; Alberts, J.R.; Ronca, A.E. Oxidative Stress as Cause, Consequence, or Biomarker of Altered Female Reproduction and Development in the Space Environment. Int. J. Mol. Sci. 2018, 19, 3729. [CrossRef]

18. Gunga, H.-C. Human Physiology in Extreme Environments; Academic Press: Boston, MA, USA, 2014; pp. $273-311$.

19. Elizabeth, A.B.; Michael, J.P.; Karen, R.J. Spaceflight Activates Autophagy Programs and the Proteasome in Mouse Liver. Int. J. Mol. Sci. 2017, 18, 2062.

20. Markolefa, I.; Lambrou, G.I. The Role of Autophagy During Osteoclastogenesis under Microgravity Conditions. Int. J. Astrobiol. 2019, 18, 384-390. [CrossRef]

21. Pajevic, P.D.; Spatz, J.M.; Garr, J.; Adamson, C.; Misener, L. Osteocyte Biology and Space Flight. Curr. Biotechnol. 2013, 2, 179-183. [CrossRef]

22. Rokhlenko, K.D.; Mul'diiarov, P. Myocardial Ultrastructure of Rats Exposed Aboard Biosatellite "Cosmos-936". Kosm. Biol. Aviakosm. Med. 1981, 15, 77-82. [PubMed]

23. Mednieks, M.I.; Hand, A.R. Salivary Gland Ultrastructure and Cyclic Amp-Dependent Reactions in Spacelab 3 Rats. Am. J. Physiol. 1987, 252, R233-R239. [CrossRef] [PubMed]

24. Gambara, G.; Salanova, M.; Ciciliot, S.; Furlan, S.; Gutsmann, M.; Schiffl, G.; Ungethuem, U.; Volpe, P.; Gunga, H.C.; Blottner, D. Microgravity-Induced Transcriptome Adaptation in Mouse Paraspinal Longissimus Dorsi Muscle Highlights Insulin Resistance-Linked Genes. Front. Physiol. 2017, 8, 279. [CrossRef] [PubMed]

25. Bradamante, S.; Rivero, D.; Barenghi, L.; Balsamo, M.; Minardi, S.P.; Vitali, F.; Cavalieri, D. Scd-Stem Cell Differentiation toward Osteoblast Onboard the International Space Station. Microgravity Sci. Technol. 2018, 30, 713-729. [CrossRef]

26. Nogues, C.; Pfister, A.; Kaiser, R. Comparative Study of Lesions in the Brain of Rats Exposed to Heavy Ions: Accelerator and Stratospheric Flight Research. Life Sci. Space Res. 1978, 16, 119-125.

27. Doty, S.B.; Morey-Holton, E. Alterations in Bone Forming Cells Due to Reduced Weight Bearing. Physiologist 1984, 27, S81-S82.

28. Dagdeviren, D.; Beallias, J.; Khan, I.; Mednieks, M.I.; Hand, A.R. Response of the Mouse Sublingual Gland to Spaceflight. Eur. J. Oral. Sci. 2018, 126, 373-381. [CrossRef]

29. Riley, D.A.; Ellis, S.; Slocum, G.R.; Satyanarayana, T.; Bain, J.L.; Sedlak, F.R. Hypogravity-Induced Atrophy of Rat Soleus and Extensor Digitorum Longus Muscles. Muscle Nerve 1987, 10, 560-568. [CrossRef]

30. Sandonà, D.; Desaphy, J.F.; Camerino, G.M.; Bianchini, E.; Ciciliot, S.; Danieli-Betto, D.; Dobrowolny, G.; Furlan, S.; Germinario, E.; Goto, K.; et al. Adaptation of Mouse Skeletal Muscle to Long-Term Microgravity in the Mds Mission. PLoS ONE 2012, 7, e33232. [CrossRef]

31. García-Ovejero, D.; Trejo, J.L.; Ciriza, I.; Walton, K.D.; García-Segura, L.M. Space Flight Affects Magnocellular Supraoptic Neurons of Young Prepuberal Rats: Transient and Permanent Effects. Dev. Brain Res. 2001, 130, 191-205. [CrossRef]

32. Rodionova, N.V.; Oganov, V.S.; Zolotova, N.V. Ultrastructural Changes in Osteocytes in Microgravity Conditions. Adv. Space Res. 2002, 30, 765-770. [CrossRef]

33. Roffino, S.; Carnino, A.; Chopard, A.; Mutin, M.; Marini, J.F. Structural Remodeling of Unweighted Soleus Myotendinous Junction in Monkey. C. R. Biol. 2006, 329, 172-179. [CrossRef] [PubMed]

34. Onishi, Y.; Hirasaka, K.; Ishihara, I.; Oarada, M.; Goto, J.; Ogawa, T.; Suzue, N.; Nakano, S.; Furochi, H.; Ishidoh, K.; et al. Identification of Mono-Ubiquitinated Ldh-a in Skeletal Muscle Cells Exposed to Oxidative Stress. Biochem. Biophys. Res. Commun. 2005, 336, 799-806. [CrossRef]

35. Tischler, M.E.; Kirby, C.; Rosenberg, S.; Tome, M.; Chase, P. Mechanisms of Accelerated Proteolysis in Rat Soleus Muscle Atrophy Induced by Unweighting or Denervation. Physiologist 1991, 34, S177-S178.

36. Taillandier, D.; Aurousseau, E.; Meynial-Denis, D.; Bechet, D.; Ferrara, M.; Cottin, P.; Ducastaing, A.; Bigard, X.; Guezennec, C.Y.; Schmid, H.P.; et al. Coordinate Activation of Lysosomal, Ca 2+-Activated and Atp-Ubiquitin-Dependent Proteinases in the Unweighted Rat Soleus Muscle. Biochem. J. 1996, 316 (Pt 1), 65-72. [CrossRef]

37. Dupont-Versteegden, E.E.; Fluckey, J.D.; Knox, M.; Gaddy, D.; Peterson, C.A. Effect of Flywheel-Based Resistance Exercise on Processes Contributing to Muscle Atrophy During Unloading in Adult Rats. J. Appl. Physiol. 2006, 101, 202-212. [CrossRef] [PubMed]

38. Ferreira, R.; Vitorino, R.; Neuparth, M.J.; Appell, H.-J.; Amado, F.; Duarte, J.A. Cellular Patterns of the Atrophic Response in Murine Soleus and Gastrocnemius Muscles Submitted to Simulated Weightlessness. Eur. J. Appl. Physiol. 2007, 101, 331-340. [CrossRef] 
39. Ferreira, R.; Neuparth, M.J.; Vitorino, R.; Appell, H.J.; Amado, F.; Duarte, J.A. Evidences of Apoptosis During the Early Phases of Soleus Muscle Atrophy in Hindlimb Suspended Mice. Physiol. Res. 2008, 57, 601-611.

40. Liu, H.; Xie, Q.; Xin, B.-M.; Liu, J.-L.; Liu, Y.; Li, Y.-Z.; Wang, J.-P. Inhibition of Autophagy Recovers Cardiac Dysfunction and Atrophy in Response to Tail-Suspension. Life Sci. 2015, 121, 1-9. [CrossRef]

41. Sambandam, Y.; Blanchard, J.J.; Daughtridge, G.; Kolb, R.J.; Shanmugarajan, S.; Pandruvada, S.N.M.; Bateman, T.A.; Reddy, S.V. Microarray Profile of Gene Expression During Osteoclast Differentiation in Modelled Microgravity. J. Cell. Biochem. 2010, 111, 1179-1187. [CrossRef]

42. Li, C.-F.; Sun, J.-X.; Gao, Y.; Shi, F.; Pan, Y.-K.; Wang, Y.-C.; Sun, X.-Q. Clinorotation-Induced Autophagy Via Hdm2-P53-Mtor Pathway Enhances Cell Migration in Vascular Endothelial Cells. Cell Death Dis. 2018, 9, 147. [CrossRef] [PubMed]

43. Ryu, H.-W.; Choi, S.-H.; Namkoong, S.; Jang, I.-S.; Seo, D.H.; Choi, I.; Kim, H.-S.; Park, J. Simulated Microgravity Contributes to Autophagy Induction by Regulating Amp-Activated Protein Kinase. DNA Cell Biol. 2014, 33, 128-135. [CrossRef] [PubMed]

44. Yoo, Y.-M.; Han, T.-Y.; Kim, H.S. Melatonin Suppresses Autophagy Induced by Clinostat in Preosteoblast Mc3t3-E1 Cells. Int. J. Mol. Sci. 2016, 17, 526. [CrossRef]

45. Arun, R.; Sivanesan, D.; Vidyasekar, P.; Verma, R. Pten/Foxo3/Akt Pathway Regulates Cell Death and Mediates Morphogenetic Differentiation of Colorectal Cancer Cells under Simulated Microgravity. Sci. Rep. 2017, 7, 5952. [CrossRef]

46. Jeong, A.J.; Kim, Y.J.; Lim, M.H.; Lee, H.; Noh, K.; Kim, B.H.; Chung, J.W.; Cho, C.H.; Kim, S.; Ye, S.K. Microgravity Induces Autophagy Via Mitochondrial Dysfunction in Human Hodgkin's Lymphoma Cells. Sci. Rep. 2018, 8, 14646. [CrossRef] [PubMed]

47. Fukazawa, T.; Tanimoto, K.; Shrestha, L.; Imura, T.; Takahashi, S.; Sueda, T.; Hirohashi, N.; Hiyama, E.; Yuge, L. Simulated Microgravity Enhances Cddp-Induced Apoptosis Signal Via P53-Independent Mechanisms in Cancer Cells. PLoS ONE 2019, 14, e0219363. [CrossRef]

48. Ferranti, F.; Caruso, M.; Cammarota, M.; Masiello, M.G.; Scheri, K.C.; Fabrizi, C.; Fumagalli, L.; Schiraldi, C.; Cucina, A.; Catizone, A.; et al. Cytoskeleton Modifications and Autophagy Induction in Tcam-2 Seminoma Cells Exposed to Simulated Microgravity. BioMed Res. Int. 2014, 2014, 904396. [CrossRef]

49. Morabito, C.; Guarnieri, S.; Catizone, A.; Schiraldi, C.; Ricci, G.; Mariggiò, M. Transient Increases in Intracellular Calcium and Reactive Oxygen Species Levels in Tcam-2 Cells Exposed to Microgravity. Sci. Rep. 2017, 7, 15648. [CrossRef]

50. Indo, H.P.; Tomiyoshi, T.; Suenaga, S.; Tomita, K.; Suzuki, H.; Masuda, D.; Terada, M.; Ishioka, N.; Gusev, O.; Cornette, R.; et al. Mnsod Downregulation Induced by Extremely Low 0.1 Mgy Single and Fractionated X-Rays and Microgravity Treatment in Human Neuroblastoma Cell Line, Nb-1. J. Clin. Biochem. Nutr. 2015, 57, 98-104. [CrossRef]

51. Cho, H.-J.; Baek, M.-O.; Khaliq, S.A.; Chon, S.J.; Son, K.H.; Lee, S.H.; Yoon, M.-S. Microgravity inhibits Decidualization Via Decreasing Akt Activity and Foxo3a Expression in Human Endometrial Stromal Cells. Sci. Rep. 2019, 9, 12094. [CrossRef]

52. Nabavi, N.; Khandani, A.; Camirand, A.; Harrison, R.E. Effects of Microgravity on Osteoclast Bone Resorption and Osteoblast Cytoskeletal Organization and Adhesion. Bone 2011, 49, 965-974. [CrossRef] [PubMed]

53. Boya, P.; Codogno, P.; Rodriguez-Muela, N. Autophagy in Stem Cells: Repair, Remodelling and Metabolic Reprogramming. Development 2018, 145, 1-14. [CrossRef] [PubMed]

54. Carmeliet, G.; Bouillon, R. The Effect of Microgravity on Morphology and Gene Expression of Osteoblasts in Vitro. FASEB J. 1999, 13, 129-134. [CrossRef]

55. Sibonga, J. Spaceflight-Induced Bone Loss: Is There an Osteoporosis Risk? Curr. Osteoporos. Rep. 2013, 11, 92-98. [CrossRef]

56. Garber, M.A.; McDowell, D.L.; Hutton, W.C. Bone Loss During Simulated Weightlessness: A Biomechanical and Mineralization Study in the Rat Model. Aviat. Space Environ. Med. 2000, 71, 586-592.

57. Lang, T.F.; Leblanc, A.D.; Evans, H.J.; Lu, Y. Adaptation of the Proximal Femur to Skeletal Reloading after Long-Duration Spaceflight. J. Bone Miner. Res. 2006, 21, 1224-1230. [CrossRef]

58. Clément, G. The Musculo-Skeletal System in Space. In Fundamentals of Space Medicine; Springer: New York, NY, USA, 2011; Volume 23, pp. 181-216.

59. Laurence, V.; Alan, H. Skeletal Changes During and after Spaceflight. Nat. Rev. Rheumatol. 2018, 14, $229-245$. 
60. Lotinun, S.; Kiviranta, R.; Matsubara, T.; Alzate, J.A.; Neff, L.; Lüth, A.; Koskivirta, I.; Kleuser, B.; Vacher, J.; Vuorio, E.; et al. Osteoclast-Specific Cathepsin K Deletion Stimulates S1p-Dependent Bone Formation. J. Clin. Invesig. 2013, 123, 666-681. [CrossRef] [PubMed]

61. Ducy, P.; Schinke, T.; Karsenty, G. The Osteoblast: A Sophisticated Fibroblast under Central Surveillance. Science 2000, 289, 1501-1504. [CrossRef]

62. Teitelbaum, S.L. Bone Resorption by Osteoclasts. Science 2000, 289, 1504-1508. [CrossRef]

63. Karsenty, G.; Kronenberg, H.M.; Settembre, C. Genetic Control of Bone Formation. Ann. Rev. Cell Dev. Biol. 2009, 25, 629-648. [CrossRef] [PubMed]

64. Iqbal, J.; Zaidi, M. Molecular Regulation of Mechanotransduction. Biochem. Biophys. Res. Commun. 2005, 328, 751-755. [CrossRef] [PubMed]

65. Spatz, J.M.; Fields, E.E.; Yu, E.W.; Pajevic, P.D.; Bouxsein, M.L.; Sibonga, J.D.; Zwart, S.R.; Smith, S.M. Serum Sclerostin Increases in Healthy Adult Men During Bed Rest. J. Clin. Endocrinol. Metab. 2012, 97, E1736-E1740. [CrossRef] [PubMed]

66. Frings-Meuthen, P.; Boehme, G.; Liphardt, A.M.; Baecker, N.; Heer, M.; Rittweger, J. Sclerostin and Dkk1 Levels During 14 and 21 Days of Bed Rest in Healthy Young Men. J. Musculoskelet Neuronal. Interact. 2013, $13,45-52$.

67. Li, X.; Zhang, Y.; Kang, H.; Liu, W.; Liu, P.; Zhang, J.; Harris, S.E.; Wu, D. Sclerostin Binds to Lrp5/6 and Antagonizes Canonical Wnt Signaling. J. Biol. Chem. 2005, 280, 19883-19887. [CrossRef]

68. Spatz, J.M.; Wein, M.N.; Gooi, J.H.; Qu, Y.; Garr, J.L.; Liu, S.; Barry, K.J.; Uda, Y.; Lai, F.; Dedic, C.; et al. The Wnt Inhibitor Sclerostin Is up-Regulated by Mechanical Unloading in Osteocytes in Vitro. J. Biol. Chem. 2015, 290, 16744-16758. [CrossRef]

69. Suen, P.K.; Qin, L. Sclerostin, an Emerging Therapeutic Target for Treating Osteoporosis and Osteoporotic Fracture: A General Review. J. Orthop. Translat. 2016, 4, 1-13. [CrossRef]

70. Whitty, C.; Wardale, R.J.; Henson, F.M.D. The Regulation of Sclerostin by Cathepsin K in Periodontal Ligament Cells. Biochem. Biophys. Res. Commun. 2018, 503, 550-555. [CrossRef]

71. Shiraki, M.; Xu, X.; Iovanna, J.L.; Kukita, T.; Hirata, H.; Kamohara, A.; Kubota, Y.; Miyamoto, H.; Mawatari, M.; Kukita, A. Deficiency of Stress-Associated Gene Nupr1 Increases Bone Volume by Attenuating Differentiation of Osteoclasts and Enhancing Differentiation of Osteoblasts. FASEB J. 2019, 33, 8836-8852. [CrossRef]

72. Gould, G.W.; Lippincott-Schwartz, J. New Roles for Endosomes: From Vesicular Carriers to Multi-Purpose Platforms. Nat. Rev. Mol. Cell Biol. 2009, 10, 287-292. [CrossRef]

73. Zhao, H. Membrane Trafficking in Osteoblasts and Osteoclasts: New Avenues for Understanding and Treating Skeletal Diseases. Traffic 2012, 13, 1307-1314. [CrossRef] [PubMed]

74. Keusch, I.; Traebert, M.; Lotscher, M.; Kaissling, B.; Murer, H.; Biber, J. Parathyroid Hormone and Dietary Phosphate Provoke a Lysosomal Routing of the Proximal Tubular Na/Pi-Cotransporter Type Ii. Kidney Int. 1998, 54, 1224-1232. [CrossRef] [PubMed]

75. Ross, W.C.; Samuel, H.G.; Jean-Pierre, V.; Thomas, J.G. Pth Receptor-1 Signalling-Mechanistic Insights and Therapeutic Prospects. Nat. Rev. Endocrinol. 2015, 11, 712-724.

76. Smith, S.M.; McCoy, T.; Gazda, D.; Morgan, J.L.L.; Heer, M.; Zwart, S.R. Space Flight Calcium: Implications for Astronaut Health, Spacecraft Operations, and Earth. Nutrients 2012, 4, 2047-2068. [CrossRef]

77. Iwase, S.; Nishimura, N.; Tanaka, K.; Mano, T. Effects of Microgravity on Human Physiology. In Beyond LEO-Human Health Issues for Deep Space Exploration; Reynolds, R.J., Ed.; IntechOpen: London, UK, 2020; pp. 1-22.

78. Florencio-Silva, R.; Sasso, G.; Simoes, M.D.; Simoes, R.; Baracat, M.; Sasso-Cerri, E.; Cerri, P.S. Osteoporosis and Autophagy: What Is the Relationship? Rev. Assoc. Med. Bras. 2017, 63, 173-179. [CrossRef]

79. Mulari, M.T.K.; Zhao, H.; Lakkakorpi, P.T.; Väänänen, H.K. Osteoclast Ruffled Border Has Distinct Subdomains for Secretion and Degraded Matrix Uptake. Traffic 2003, 4, 113-125. [CrossRef]

80. Palokangas, H.; Mulari, M.; Väänänen, H.K. Endocytic Pathway from the Basal Plasma Membrane to the Ruffled Border Membrane in Bone-Resorbing Osteoclasts. J. Cell Sci. 1997, 110, 1767-1780.

81. Van Loon, J.J.; Bervoets, D.J.; Burger, E.H.; Dieudonné, S.C.; Hagen, J.W.; Semeins, C.M.; Doulabi, B.Z.; Veldhuijzen, J.P. Decreased Mineralization and Increased Calcium Release in Isolated Fetal Mouse Long Bones under near Weightlessness. J. Bone Miner. Res. 1995, 10, 550-557. [CrossRef]

82. Hughes-Fulford, M.; Lewis, M.L. Effects of Microgravity on Osteoblast Growth Activation. Exp. Cell Res. 1996, 224, 103-109. [CrossRef] 
83. Rucci, N.; Migliaccio, S.; Zani, B.M.; Taranta, A.; Teti, A. Characterization of the Osteoblast-Like Cell Phenotype under Microgravity Conditions in the Nasa-Approved Rotating Wall Vessel Bioreactor (Rwv). J. Cell. Biochem. 2002, 85, 167-179. [CrossRef]

84. Lacombe, J.; Karsenty, G.; Ferron, M. Regulation of Lysosome Biogenesis and Functions in Osteoclasts. Cell Cycle 2013, 12, 2744-2752. [CrossRef] [PubMed]

85. Blaber, E.; Sato, K.; Almeida, E.A.C. Stem Cell Health and Tissue Regeneration in Microgravity. Stem Cells Dev. 2014, 23 (Suppl 1), 73-78. [CrossRef] [PubMed]

86. Zhao, H.; Laitala-Leinonen, T.; Parikka, V.; Vaananen, H.K. Downregulation of Small Gtpase Rab7 Impairs Osteoclast Polarization and Bone Resorption. J. Biol. Chem. 2001, 276, 39295-39302. [CrossRef]

87. Clement, J. Gene Expression Microarrays in Microgravity Research: Toward the Identification of Major Space Genes. In Innovations of Biotechnology; Agbo, E.C., Ed.; IntechOpen: London, UK, 2012; pp. 319-348.

88. Ethiraj, P.; Ottinger, A.M.; Singh, T.; Singh, A.; Haire, K.M.; Reddy, S.V. Proteasome Inhibition Suppress Microgravity Elevated Rank Signaling During Osteoclast Differentiation. Cytokine 2020, 125, 154821. [CrossRef]

89. Nakamura, S.; Shigeyama, S.; Minami, S.; Shima, T.; Akayama, S.; Matsuda, T.; Esposito, A.; Napolitano, G.; Kuma, A.; Namba-Hamano, T.; et al. Lc3 Lipidation Is Essential for Tfeb Activation During the Lysosomal Damage Response to Kidney Injury. Nat. Cell Biol. 2020, 22, 1252-1263. [CrossRef] [PubMed]

90. Sardiello, M.; Palmieri, M.; di Ronza, A.; Medina, D.L.; Valenza, M.; Gennarino, V.A.; Di Malta, C.; Donaudy, F.; Embrione, V.; Polishchuk, R.S.; et al. A Gene Network Regulating Lysosomal Biogenesis and Function. Science 2009, 325, 473-477. [CrossRef]

91. Gao, M.; Gao, W.; Papadimitriou, J.M.; Zhang, C.; Gao, J.; Zheng, M. Exosomes-the Enigmatic Regulators of Bone Homeostasis. Bone Res. 2018, 6, 36. [CrossRef]

92. Guo, H.; Chitiprolu, M.; Roncevic, L.; Javalet, C.; Hemming, F.J.; Trung, M.T.; Meng, L.; Latreille, E.; Tanese de Souza, C.; McCulloch, D.; et al. Atg5 Disassociates the V1v0-Atpase to Promote Exosome Production and Tumor Metastasis Independent of Canonical Macroautophagy. Dev. Cell 2017, 43, 716-730. [CrossRef]

93. Gudbergsson, J.M.; Johnsen, K.B. Exosomes and Autophagy: Rekindling the Vesicular Waste Hypothesis. J. Cell. Commun. Signal. 2019, 13, 443-450. [CrossRef]

94. Ralston, E.; Lu, Z.; Ploug, T. The Organization of the Golgi Complex and Microtubules in Skeletal Muscle Is Fiber Type-Dependent. J. Neurosci. 1999, 19, 10694-10705. [CrossRef]

95. Grumati, P.; Coletto, L.; Sabatelli, P.; Cescon, M.; Angelin, A.; Bertaggia, E.; Blaauw, B.; Urciuolo, A.; Tiepolo, T.; Merlini, L.; et al. Autophagy Is Defective in Collagen Vi Muscular Dystrophies, and Its Reactivation Rescues Myofiber Degeneration. Nat. Med. 2010, 16, 1313-1320. [CrossRef] [PubMed]

96. Penna, F.; Costamagna, D.; Pin, F.; Camperi, A.; Fanzani, A.; Chiarpotto, E.M.; Cavallini, G.; Bonelli, G.; Baccino, F.M.; Costelli, P. Autophagic Degradation Contributes to Muscle Wasting in Cancer Cachexia. Am. J. Pathol. 2013, 182, 1367-1378. [CrossRef]

97. Brocca, L.; Cannavino, J.; Coletto, L.; Biolo, G.; Sandri, M.; Bottinelli, R.; Pellegrino, M.A. The Time Course of the Adaptations of Human Muscle Proteome to Bed Rest and the Underlying Mechanisms. J. Physiol. 2012, 590, 5211-5230. [CrossRef] [PubMed]

98. Hargens, A.R.; Bhattacharya, R.; Schneider, S.M. Space Physiology Vi: Exercise, Artificial Gravity, and Countermeasure Development for Prolonged Space Flight. Eur. J. Appl. Physiol. 2013, 113, 2183-2192. [CrossRef]

99. Wang, X.; Blagden, C.; Fan, J.; Nowak, S.; Taniuchi, I.; Littman, D.; Burden, S. Runx1 Prevents Wasting, Myofibrillar Disorganization, and Autophagy of Skeletal Muscle. Genes Dev. 2005, 19, 1715-1722. [CrossRef] [PubMed]

100. Stein, T.P.; Schluter, M.D. Excretion of Amino Acids by Humans During Space Flight. Acta Astronaut. 1998, 42, 205-214. [CrossRef]

101. Fitts, R.H.; Trappe, S.W.; Costill, D.L.; Gallagher, P.M.; Creer, A.C.; Colloton, P.A.; Peters, J.R.; Romatowski, J.G.; Bain, J.L.; Riley, D.A. Prolonged Space Flight-Induced Alterations in the Structure and Function of Human Skeletal Muscle Fibres. J. Physiol. 2010, 588, 3567-3592. [CrossRef]

102. Choi, S.Y.; Saravia-Butler, A.; Shirazi-Fard, Y.; Leveson-Gower, D.; Stodieck, L.S.; Cadena, S.M.; Beegle, J.; Solis, S.; Ronca, A.; Globus, R.K. Validation of a New Rodent Experimental System to Investigate Consequences of Long Duration Space Habitation. Sci. Rep. 2020, 10, 2336. [CrossRef] 
103. Hanna, R.A.; Quinsay, M.N.; Orogo, A.M.; Giang, K.; Rikka, S.; Gustafsson, A.B. Microtubule-Associated Protein 1 Light Chain 3 (Lc3) Interacts with Bnip3 Protein to Selectively Remove Endoplasmic Reticulum and Mitochondria Via Autophagy. J. Biol. Chem. 2012, 287, 19094-19104. [CrossRef]

104. Romanello, V.; Sandri, M. Mitochondrial Biogenesis and Fragmentation as Regulators of Muscle Protein Degradation. Curr. Hypertens. Rep. 2010, 12, 433-439. [CrossRef]

105. Zhao, T.; Tang, X.; Umeshappa, C.S.; Ma, H.; Gao, H.; Deng, Y.; Freywald, A.; Xiang, J. Simulated Microgravity Promotes Cell Apoptosis through Suppressing Uev1a/Ticam/Traf/Nf-Kappab-Regulated Anti-Apoptosis and P53/Pcna- and Atm/Atr-Chk1/2-Controlled DNA-Damage Response Pathways. J. Cell Biochem. 2016, 117, 2138-2148. [CrossRef]

106. Ma, X.; Godar, R.J.; Liu, H.; Diwan, A. Enhancing Lysosome Biogenesis Attenuates Bnip3-Induced Cardiomyocyte Death. Autophagy 2012, 8, 297-309. [CrossRef]

107. Mansueto, G.; Armani, A.; Viscomi, C.; D’Orsi, L.; De Cegli, R.; Polishchuk, E.V.; Lamperti, C.; Di Meo, I.; Romanello, V.; Marchet, S.; et al. Transcription Factor Eb Controls Metabolic Flexibility During Exercise. Cell Metab. 2017, 25, 182-196. [CrossRef] [PubMed]

108. Wang, S.; Chen, Y.; Li, X.; Zhang, W.; Liu, Z.; Wu, M.; Pan, Q.; Liu, H. Emerging Role of Transcription Factor Eb in Mitochondrial Quality Control. Biomed. Pharmacother. 2020, 128, 110272. [CrossRef] [PubMed]

109. Milan, G.; Romanello, V.; Pescatore, F.; Armani, A.; Paik, J.H.; Frasson, L.; Seydel, A.; Zhao, J.; Abraham, R.; Goldberg, A.L.; et al. Regulation of Autophagy and the Ubiquitin-Proteasome System by the Foxo Transcriptional Network During Muscle Atrophy. Nat. Commun. 2015, 6, 6670. [CrossRef]

110. Zhao, J.; Brault, J.J.; Schild, A.; Cao, P.; Sandri, M.; Schiaffino, S.; Lecker, S.H.; Goldberg, A.L. Foxo3 Coordinately Activates Protein Degradation by the Autophagic/Lysosomal and Proteasomal Pathways in Atrophying Muscle Cells. Cell Metab. 2007, 6, 472-483. [CrossRef]

111. Ehmsen, J.T.; Hoke, A. Cellular and Molecular Features of Neurogenic Skeletal Muscle Atrophy. Exp. Neurol. 2020, 331, 113379. [CrossRef] [PubMed]

112. Kong, Y.; Liu, H.; Li, W.; Wang, D. Intestine-Specific Activity of Insulin Signaling Pathway in Response to Microgravity Stress in Caenorhabditis Elegans. Biochem. Biophys. Res. Commun. 2019, 517, 278-284. [CrossRef]

113. Sun, Y.; Li, M.; Zhao, D.; Li, X.; Yang, C.; Wang, X. Lysosome Activity Is Modulated by Multiple Longevity Pathways and Is Important for Lifespan Extension in C. Elegans. Elife 2020, 9, e55745. [CrossRef]

114. Tharyan, R.G.; Annibal, A.; Schiffer, I.; Laboy, R.; Atanassov, I.; Weber, A.L.; Gerisch, B.; Antebi, A. Nfyb-1 Regulates Mitochondrial Function and Longevity Via Lysosomal Prosaposin. Nat. Metab. 2020, 2, 387-396. [CrossRef]

115. Gustafsson, T.; Osterlund, T.; Flanagan, J.N.; von Walden, F.; Trappe, T.A.; Linnehan, R.M.; Tesch, P.A. Effects of 3 Days Unloading on Molecular Regulators of Muscle Size in Humans. J. Appl. Physiol. 2010, 109, 721-727. [CrossRef] [PubMed]

116. Aston, D.; Capel, R.A.; Ford, K.L.; Christian, H.C.; Mirams, G.R.; Rog-Zielinska, E.A.; Kohl, P.; Galione, A.; Burton, R.A.; Terrar, D.A. High Resolution Structural Evidence Suggests the Sarcoplasmic Reticulum Forms Microdomains with Acidic Stores (Lysosomes) in the Heart. Sci. Rep. 2017, 7, 40620. [CrossRef] [PubMed]

117. Kinnear, N.P.; Boittin, F.X.; Thomas, J.M.; Galione, A.; Evans, A.M. Lysosome-Sarcoplasmic Reticulum Junctions. A Trigger Zone for Calcium Signaling by Nicotinic Acid Adenine Dinucleotide Phosphate and Endothelin-1. J. Biol. Chem. 2004, 279, 54319-54326. [CrossRef] [PubMed]

118. Bootman, M.D.; Chehab, T.; Bultynck, G.; Parys, J.B.; Rietdorf, K. The Regulation of Autophagy by Calcium Signals: Do We Have a Consensus? Cell Calcium. 2018, 70, 32-46. [CrossRef]

119. Ho, T.T.; Warr, M.R.; Adelman, E.R.; Lansinger, O.M.; Flach, J.; Verovskaya, E.V.; Figueroa, M.E.; Passegue, E. Autophagy Maintains the Metabolism and Function of Young and Old Stem Cells. Nature 2017, 543, $205-210$. [CrossRef]

120. Yamaguchi, Y.; Sakai, E.; Okamoto, K.; Kajiya, H.; Okabe, K.; Naito, M.; Kadowaki, T.; Tsukuba, T. Rab44, a Novel Large Rab Gtpase, Negatively Regulates Osteoclast Differentiation by Modulating Intracellular Calcium Levels Followed by Nfatc1 Activation. Cell Mol. Life Sci. 2018, 75, 33-48. [CrossRef]

121. Erkhembaatar, M.; Gu, D.R.; Lee, S.H.; Yang, Y.M.; Park, S.; Muallem, S.; Shin, D.M.; Kim, M.S. Lysosomal Ca2+ Signaling Is Essential for Osteoclastogenesis and Bone Remodeling. J. Bone Miner. Res. 2017, 32, 385-396. [CrossRef] 
122. Villegas, F.; Lehalle, D.; Mayer, D.; Rittirsch, M.; Stadler, M.B.; Zinner, M.; Olivieri, D.; Vabres, P.; Duplomb-Jego, L.; De Bont, E.; et al. Lysosomal Signaling Licenses Embryonic Stem Cell Differentiation Via Inactivation of Tfe3. Cell Stem Cell. 2019, 24, 257-270. [CrossRef]

123. Chang, N.C. Autophagy and Stem Cells: Self-Eating for Self-Renewal. Front. Cell Dev. Biol. 2020, 8, 138. [CrossRef]

124. Zakrzewski, W.; Dobrzyński, M.; Szymonowicz, M.; Rybak, Z. Stem Cells: Past, Present, and Future. Stem Cell Res. Ther. 2019, 10, 68. [CrossRef]

125. Grimm, D.; Wehland, M.; Corydon, T.J.; Richter, P.; Prasad, B.; Bauer, J.; Egli, M.; Kopp, S.; Lebert, M.; Krüger, M. The Effects of Microgravity on Differentiation and Cell Growth in Stem Cells and Cancer Stem Cells. Stem Cells Transl. Med. 2020, 9, 882-894. [CrossRef] [PubMed]

126. Kopp, S.; Warnke, E.; Wehland, M.; Aleshcheva, G.; Magnusson, N.E.; Hemmersbach, R.; Corydon, T.J.; Bauer, J.; Infanger, M.; Grimm, D. Mechanisms of Three-Dimensional Growth of Thyroid Cells During Long-Term Simulated Microgravity. Sci. Rep. 2015, 5, 16691. [CrossRef]

127. White, E. Deconvoluting the Context-Dependent Role for Autophagy in Cancer. Nat. Rev. Cancer 2012, 12, 401-410. [CrossRef] [PubMed]

128. Hynds, R.E.; Vladimirou, E.; Janes, S.M. The Secret Lives of Cancer Cell Lines. Dis. Model Mech. 2018, 11, dmm037366. [CrossRef] [PubMed]

129. Pavlakou, P.; Dounousi, E.; Roumeliotis, S.; Eleftheriadis, T.; Liakopoulos, V. Oxidative Stress and the Kidney in the Space Environment. Int. J. Mol. Sci. 2018, 19, 3176. [CrossRef]

130. Haigis, M.C.; Yankner, B.A. The Aging Stress Response. Mol. Cell 2010, 40, 333-344. [CrossRef]

131. Limoli, C.L.; Giedzinski, E.; Rola, R.; Otsuka, S.; Palmer, T.D.; Fike, J.R. Radiation Response of Neural Precursor Cells: Linking Cellular Sensitivity to Cell Cycle Checkpoints, Apoptosis and Oxidative Stress. Radiat. Res. 2004, 161, 17-27. [CrossRef]

132. Mavragani, I.V.; Nikitaki, Z.; Souli, M.P.; Aziz, A.; Nowsheen, S.; Aziz, K.; Rogakou, E.; Georgakilas, A.G. Complex DNA Damage: A Route to Radiation-Induced Genomic Instability and Carcinogenesis. Cancers 2017, 9, 91. [CrossRef]

133. Spitz, D.R.; Hauer-Jensen, M. Ionizing Radiation-Induced Responses: Where Free Radical Chemistry Meets Redox Biology and Medicine. Antioxid. Redox. Signal. 2014, 20, 1407-1409. [CrossRef]

134. Ishikawa, K.; Takenaga, K.; Akimoto, M.; Koshikawa, N.; Yamaguchi, A.; Imanishi, H.; Nakada, K.; Honma, Y.; Hayashi, J. Ros-Generating Mitochondrial DNA Mutations Can Regulate Tumor Cell Metastasis. Science 2008, 320, 661-664. [CrossRef]

135. Stein, T.P. Space Flight and Oxidative Stress. Nutrition 2002, 18, 867-871. [CrossRef]

136. Yamamori, T.; Yasui, H.; Yamazumi, M.; Wada, Y.; Nakamura, Y.; Nakamura, H.; Inanami, O. Ionizing Radiation Induces Mitochondrial Reactive Oxygen Species Production Accompanied by Upregulation of Mitochondrial Electron Transport Chain Function and Mitochondrial Content under Control of the Cell Cycle Checkpoint. Free Radic. Biol. Med. 2012, 53, 260-270. [CrossRef]

137. Versari, S.; Longinotti, G.; Barenghi, L.; Maier, J.A.; Bradamante, S. The Challenging Environment on Board the International Space Station Affects Endothelial Cell Function by Triggering Oxidative Stress through Thioredoxin Interacting Protein Overexpression: The Esa-Sphinx Experiment. FASEB J. 2013, 27, 4466-4475. [CrossRef] [PubMed]

138. Ran, F.; An, L.; Fan, Y.; Hang, H.; Wang, S. Simulated Microgravity Potentiates Generation of Reactive Oxygen Species in Cells. Biophy. Rep. 2016, 2, 100-105. [CrossRef]

139. Yun, H.R.; Jo, Y.H.; Kim, J.; Shin, Y.; Kim, S.S.; Choi, T.G. Roles of Autophagy in Oxidative Stress. Int. J. Mol. Sci. 2020, 21, 3289. [CrossRef]

140. Cao, Q.; Yang, Y.; Zhong, X.Z.; Dong, X.-P. The Lysosomal Ca Release Channel Trpml1 Regulates Lysosome Size by Activating Calmodulin. J. Biol. Chem. 2017, 292, 8424-8435. [CrossRef]

141. Todkar, K.; Ilamathi, H.S.; Germain, M. Mitochondria and Lysosomes: Discovering Bonds. Front.Cell Dev. Biol. 2017, 5, 106. [CrossRef]

142. Ushio-Fukai, M. Localizing Nadph Oxidase-Derived Ros. Sci. STKE 2006, 2006, re8. [CrossRef] [PubMed]

143. Davis Volk, A.P.; Moreland, J.G. Ros-Containing Endosomal Compartments: Implications for Signaling. Methods Enzymol. 2014, 535, 201-224.

144. Li, L.; Tan, J.; Miao, Y.; Lei, P.; Zhang, Q. Ros and Autophagy: Interactions and Molecular Regulatory Mechanisms. Cell Mol. Neurobiol. 2015, 35, 615-621. [CrossRef] 
145. Harrison, I.P.; Vinh, A.; Johnson, I.R.D.; Luong, R.; Drummond, G.R.; Sobey, C.G.; Tiganis, T.; Williams, E.D.; O'Leary, J.J.; Brooks, D.A.; et al. Nox2 Oxidase Expressed in Endosomes Promotes Cell Proliferation and Prostate Tumour Development. Oncotarget 2018, 9, 35378-35393. [CrossRef] [PubMed]

146. Tsubata, T. Involvement of Reactive Oxygen Species (Ros) in Bcr Signaling as a Second Messenger. Adv. Exp. Med. Biol. 2020, 1254, 37-46.

147. Karunakaran, U.; Elumalai, S.; Moon, J.S.; Won, K.C. Cd36 Dependent Redoxosomes Promotes Ceramide-Mediated Pancreatic Beta-Cell Failure Via P66shc Activation. Free Radic. Biol. Med. 2019, 134, 505-515. [CrossRef] [PubMed]

148. Stein, T.P.; Schulter, M.D.; Boden, G. Development of Insulin Resistance by Astronauts During Spaceflight. Aviat. Space Environ. Med. 1994, 65, 1091-1096. [PubMed]

149. Hughson, R.L.; Robertson, A.D.; Arbeille, P.; Shoemaker, J.K.; Rush, J.W.; Fraser, K.S.; Greaves, D.K. Increased Postflight Carotid Artery Stiffness and Inflight Insulin Resistance Resulting from 6-Mo Spaceflight in Male and Female Astronauts. Am. J. Physiol. Heart Circ. Physiol. 2016, 310, H628-H638. [CrossRef] [PubMed]

150. Tiganis, T. Reactive Oxygen Species and Insulin Resistance: The Good, the Bad and the Ugly. Trends Pharmacol. Sci. 2011, 32, 82-89. [CrossRef]

151. Mann, V.; Sundaresan, A.; Mehta, S.K.; Crucian, B.; Doursout, M.F.; Devakottai, S. Effects of Microgravity and Other Space Stressors in Immunosuppression and Viral Reactivation with Potential Nervous System Involvement. Neurol. India 2019, 67, 198-203.

152. Blaber, E.A.; Dvorochkin, N.; Torres, M.L.; Yousuf, R.; Burns, B.P.; Globus, R.K.; Almeida, E.A.C. Mechanical Unloading of Bone in Microgravity Reduces Mesenchymal and Hematopoietic Stem Cell-Mediated Tissue Regeneration. Stem Cell Res. 2014, 13, 181-201. [CrossRef]

153. Lee, J.; Kim, H.R.; Quinley, C.; Kim, J.; Gonzalez-Navajas, J.; Xavier, R.; Raz, E. Autophagy Suppresses Interleukin-1 $\beta$ (Il-1 $\beta$ ) Signaling by Activation of P62 Degradation Via Lysosomal and Proteasomal Pathways. J. Biol. Chem. 2012, 287, 4033-4040. [CrossRef]

154. Nedergaard, A.; Karsdal, M.A.; Sun, S.; Henriksen, K. Serological Muscle Loss Biomarkers: An Overview of Current Concepts and Future Possibilities. J. Cachexia Sarcopenia Muscle 2013, 4, 1-17. [CrossRef]

155. Diebold, B.A.; Smith, S.M.E.; Li, Y.; Lambeth, J.D. Nox2 as a Target for Drug Development: Indications, Possible Complications, and Progress. Antioxid. Redox Signal. 2015, 23, 375-405. [CrossRef] [PubMed]

156. Mao, X.W.; Nishiyama, N.C.; Pecaut, M.J.; Campbell-Beachler, M.; Gifford, P.; Haynes, K.E.; Becronis, C.; Gridley, D.S. Simulated Microgravity and Low-Dose/Low-Dose-Rate Radiation Induces Oxidative Damage in the Mouse Brain. Radiat. Res. 2016, 185, 647-657. [CrossRef]

157. Corydon, T.J.; Kopp, S.; Wehland, M.; Braun, M.; Schutte, A.; Mayer, T.; Hulsing, T.; Oltmann, H.; Schmitz, B.; Hemmersbach, R.; et al. Alterations of the Cytoskeleton in Human Cells in Space Proved by Life-Cell Imaging. Sci. Rep. 2016, 6, 20043. [CrossRef]

158. Thiel, C.S.; Tauber, S.; Lauber, B.; Polzer, J.; Seebacher, C.; Uhl, R.; Neelam, S.; Zhang, Y.; Levine, H.; Ullrich, O. Rapid Morphological and Cytoskeletal Response to Microgravity in Human Primary Macrophages. Int. J. Mol. Sci. 2019, 20, 2402. [CrossRef]

159. Thiel, C.S.; Tauber, S.; Seebacher, C.; Schropp, M.; Uhl, R.; Lauber, B.; Polzer, J.; Neelam, S.; Zhang, Y.; Ullrich, O. Real-Time 3d High-Resolution Microscopy of Human Cells on the International Space Station. Int. J. Mol. Sci. 2019, 20, 2033. [CrossRef]

Publisher's Note: MDPI stays neutral with regard to jurisdictional claims in published maps and institutional affiliations.

(C) 2020 by the authors. Licensee MDPI, Basel, Switzerland. This article is an open access article distributed under the terms and conditions of the Creative Commons Attribution (CC BY) license (http://creativecommons.org/licenses/by/4.0/). 